\title{
IMMUNOLOGY AND PLACENTATION IN VIVIPAROUS INVERTEBRATES
}

\author{
M. D. KAYE, W. R. JONES AND D. T. ANDERSON \\ Departments of Obstetrics and Gynaecology and Biology, \\ University of Sydney, Sydney, New South Wales
}

(Received 30th May 1972, accepted 23rd June 1972)

The delayed rejection of allografted tissue in the presence of specific antibodies (Kaliss, 1958, 1962) has been considered as a possible mechanism for the maintenance of the fetal-maternal relationship in mammalian reproduction. Experiments which demonstrate the abrogation of cellular immunity to mouse embryonic cells by serum from pregnant or multiparous female strain animals have been taken to indicate that specific 'blocking' antibodies might prevent the cytotoxic action of maternal lymphocytes on embryonic cells (Hellstrom, Hellstrom \& Braun, 1969). In turn, it has been suggested (Hellstrom \& Hellstrom, 1970) that this might be the mechanism underlying the paradoxical survival of the mammalian conceptus as an allograft.

The existence of immunological enhancement, as this phenomenon is called, depends on the simultaneous presence in a particular system of both humoral and cellular immunity. It can be asked, therefore, what is the relationship between immunity and placentation in other phyla in which placentation of the embryo occurs? Although viviparity is widespread among invertebrates, being found in the Platyhelminthes, Nemertea, Annelida, Onychophora, Insecta, Arachnida, Tunicata and others, placentation of the embryo is rare. The best known examples are certain Dermaptera (Hagen, 1951), the Salpidae among the Tunicata (Berrill, 1950; Sutton, 1960) and the neotropical Onychophora. Of these, the placental development of the Onychophora is the only case markedly analogous to that of mammals. Anderson \& Manton (1972) have recently examined the fetal-maternal relationship in detail in two species of Onychophora from Trinidad, Epiperipatus trinidadensis and Macroperipatus torquatus. Each embryo develops a stalked placenta, analogous to the yolk-sac placenta of mammals. The placenta becomes intimately associated with the tissues of the oviduct wall, which in turn become highly modified in the placentation zone. The duration of the placental attachment is not known with certainty, but the rate of embryonic development and the intervals between successive parturitions are such as to indicate a placental gestation of several months.

The Onychophora have not yet been characterized immunologically, but it is well known that the Annelida, Mollusca and Insecta, invertebrate groups which probably have a distant phylogenetic relationship with the Onychophora and exhibit the same general level of morphological complexity, display cellular immunity in the virtual absence of humoral immunity. In earthworms, for 
example, bacterial antigens fail to evoke a specific humoral response, but xenogeneic tissue grafts, although they heal in well, are rejected within 25 to 26 days. Second set xenografts then elicit a specific and anamnestic response which is capable of adoptive cell transfer (Cooper, 1971). Similarly, in oysters, there is no demonstrable specific response to antigenic challenge, but evidence exists of a differential immunological recognition of isografts, allografts and xenografts at the cellular level (Cheng, 1970; Tripp, 1970). Again, among the insects, there is no convincing evidence of humoral immunity, although non-specific antibacterial activity can be demonstrated in the haemolymph of some species (Hink, 1970; Scott, 1971a). Cellular immunity is not universal in insects, as witnessed by the successful culture of imaginal discs in host larvae and adults in vivo, but cockroaches show a rapid haemocytic encapsulation and subsequent rejection of heterografts (Scott, 1971b).

It can be inferred from these examples that cellular immunity probably exists in the Onychophora and humoral immunity probably does not. The occurrence of placentation, inclusive of maternal modifications, in the Onychophora therefore argues against an important rôle for immunological enhancement in this biological phenomenon. It seems likely that the fetal-maternal relationship in mammals is founded on a simpler mechanism, such as some form of cellular communication at the interface between the two organisms (Larsen, 1970; Wilson \& Smith, 1970).

\section{REFERENCES}

Anderson, D. T. \& Manton, S. M. (1972) Studies on the Onychophora. VIII. The relationship between the embryo and oviduct in the uniparous placental Onychophorus, Epiperipatus, Trinidadensis and Macroperipatus Terquatus from Trinidad. Phil. Trans. R. Soc. (in press).

Berrill, N. J. (1950) Budding and development in Salpa. F. Morph. 87, 553.

Cheng, T. C. (1970) Immunity in mullusca with special reference to reactions to transplants. Transplant. Proc. 2, 226.

COOPER, E. L. (1971) Phylogeny of transplantation immunity: graft rejection in earthworms. Transplant. Proc. 3, 214.

Hagen, H. R. (1951) Embryology of viviparous insects, p. 261. Ronald Press, New York.

Hellstrom, K. E. \& Helzstrom, I. (1970) Immunological enhancement as studied by cell culture techniques. A. Rev. Microbiol. 24, 373.

Hellstrom, K. E., Hellstrom, I. \& Braun, J. (1969) Abrogation of cellular immunity to antigenically foreign mouse embryonic cells by a serum factor. Nature, Lond. 224, 914.

Hink, W. F. (1970) Immunity in insects. Transplant. Proc. 2, 233.

Kaliss, N. (1958) Immunological enhancement of tumour homografts in mice. Cancer Res. 18, 992.

Kaliss, N. (1962) The elements of immunological enhancement: a consideration of mechanisms. Ann. N.Y. Acad. Sci. 101, 64.

LARSEN, J. F. (1970) Electron microscopy of nidation in the rabbit and observations on the human trophoblastic invasion. In: Ovo-implantation, Human Gonadotrophins and Prolactin, p. 38. Eds. P. O. Hubinot, F. Leroy, G. Robyn and P. S. Leleux. Karger, New York.

ScotT, M. T. (1971a) Recognition of foreignness in invertebrates. II. In vitro studies of cockroach phagocytic haemacytes. Immunology, 21, 817.

ScotT, M. T. (1971b) Recognition of foreignness in invertebrates. Transplantation studies using the American cockroach. Transplant. 2, 78.

Sutton, M. J. (1960) The sexual development of Salpa fusiformis. 7. Embryol. exp. Morph. 8, 268.

Tripp, M. R. (1970) Immunity in Mollusca. Transpl. Proc. 2, 231.

Wilson, I. B. \& S Sith, M. S. R. (1970) Primary trophoblastic invasion at the time of nidation. In: Ovoimplantation, Human Gonadotrophins and Prolactin, p. 1. Eds. P. O. Hubinot, F. Leroy, G. Robyn and P. S. Leleux. Karger, New York. 